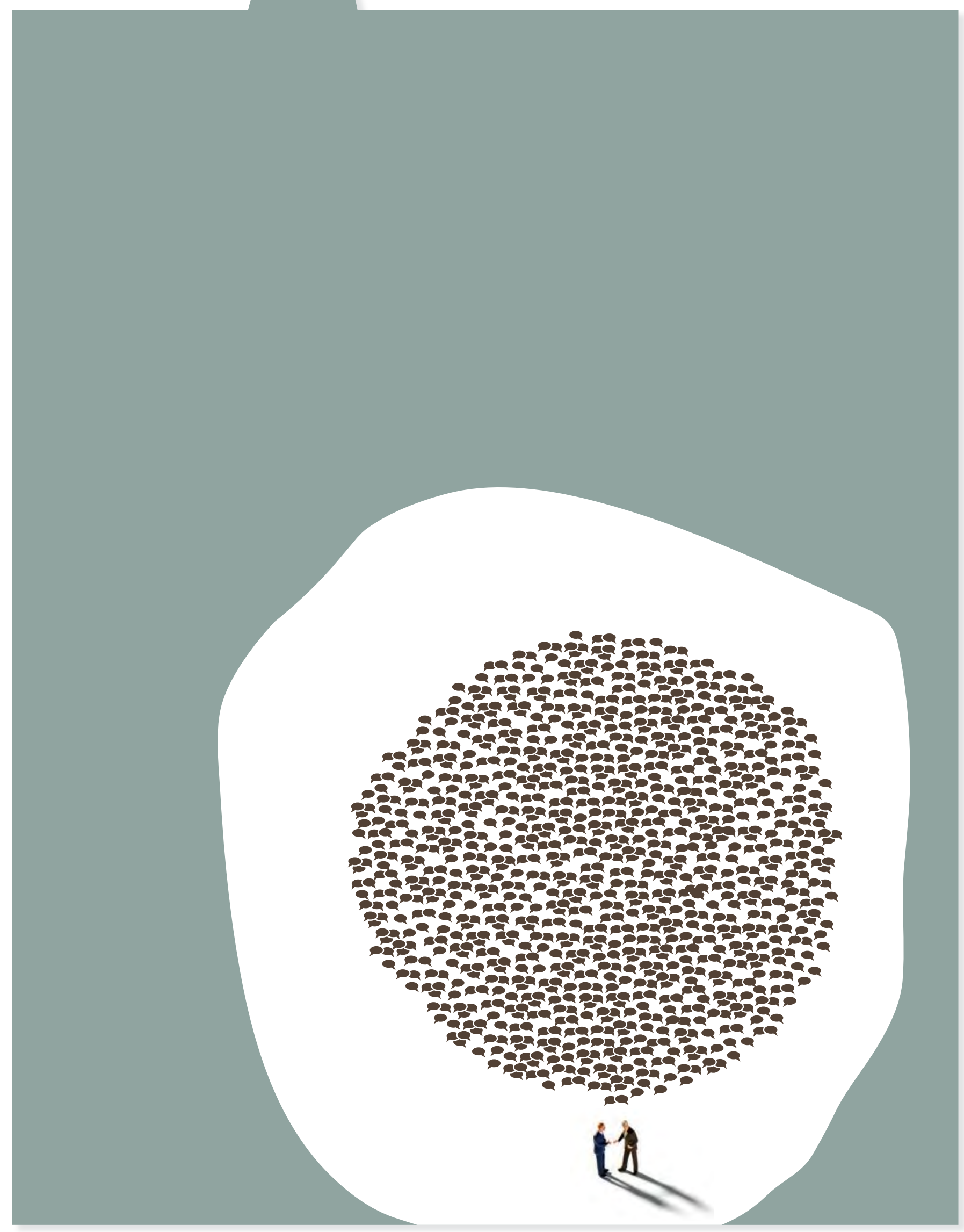




\title{
HOW COMPANIES CAN MEASURE THE SUCCESS OF THEIR RELATIONSHIP MARKETING INVESTMENTS
}

\author{
Robert Palmatier, Srinath Gopalakrishna and Mark Houston
}

\begin{abstract}
Firms invest heavily in different types of business-tobusiness relationship marketing in the belief that it bolsters their bottom line. How effective is this investment, and how can companies measure its success? This study analyzes the various aspects of business-to-business relationship marketing. Data from a matched set of 313 business customers covered by 143 salespeople employed by 34 selling firms indicates that investments in social relationship marketing pay off handsomely, financial relationship marketing does not, and structural relationship marketing is economically viable for customers serviced frequently.
\end{abstract}

The authors view relationship marketing in a context involving relevant participants (customers, salespeople and selling firms). Across the three hierarchical levels, the impact of the financial, social and structural components of relationship marketing investments, and the potential moderating factors, offer valuable insights into contextual factors and managerial strategies for leveraging these investments. The analysis is extended to a resource allocation model that describes the optimal mix of relationship marketing resources based on firm strategies.

Relationship marketing: the path to success or failure? Relationship marketing has undergone explosive growth during the last decade, due to the widespread belief that it leads to improved financial performance. However, empirical evidence on this topic is mixed, and more research is needed to isolate the conditions where relationship marketing is effective. So far, no studies have documented the returns from specific B2B investments in relationship marketing programs, or explained how to leverage these investments for specific customers.

Two aspects complicate any investigation of the customer-specific payoffs of relationship marketing. The first is the fact that different relationship marketing programs (financial, social, and structural) may build different types of relational bonds and norms that generate varying levels of return. This observation implies that investment returns may vary by program, and must be isolated to unravel the distinct effects that are masked within an aggregate measure.

The second aspect is that the returns from such programs may vary according to factors associated with any of the relational participants (customer, salesperson, selling firm), but the factors for each participant influence a different set of relational bonds. Customer factors affect returns from relationship marketing investments only for that customer, whereas salesperson factors influence the efficacy of relationship investments for all customers handled by that salesperson, and selling-firm factors leverage investments across all the customers of a selling firm. This suggests that each participant's perspective should be considered when investigating the factors and strategies that may leverage the effect of relationship marketing investment on returns.

\section{THE AUTHORS}

Robert W. Palmatier, University of Washington, palmatrw@u.washington.edu

Srinath Gopalakrishna, University of MissouriColumbia, srinath@missouri.edu

Mark Houston, University of MissouriColumbia, houstonmb@missouri.edu

The article is based with the permission of INFORMS on: Palmatier, R.W., Gopalakrishna, S. and Houston, M. B. (2006), "Returns on businessto-business relationship marketing investments: Strategies for leveraging profits", Marketing Science, Vol. 25, No. 5, pp 477-493. 
This study examines the customer-specific return (CSR) - a marginal return on investment - of relationship marketing efforts in a business-to-business (B2B) context within three nested levels of data: 313 customers served by 143 salespeople from 34 selling firms. The relationship marketing efforts are categorized into three components: financial, social and structural. Each component is examined to assess how it can generate distinctive customer bonds and norms, and whether the program will eventually pay off. Furthermore, customer, salesperson, and selling-firm factors that may leverage the payoffs are analyzed. Finally, using a resource allocation model, guidance is provided on spending levels for each type of program, contingent on salesperson and sellingfirm factors.

\section{») Because relationship marketing programs operate through different relational mechanisms, each program must be evaluated separately in order to determine whether a proposed moderator alters a customer's relational motivation or perceived value. «}

The influence of relationship marketing investments on CSR

Studies in B2B and consumer markets show that relationship marketing efforts affect a customer's value to the firm by increasing the length, breadth and depth of the buying relationship and generating positive word of mouth. Different relationship marketing activities may also generate distinctive customer bonds and relational norms, affect the relationship unevenly and thereby vary in terms of economic returns. Relationship marketing efforts must therefore be broken down into components prior to any evaluation of customer-specific economic returns.

\section{Relationship marketing investments}

Although diverse typologies and criteria exist to describe relationship marketing efforts, most include financial, social and structural components and suggest that customer-seller linkages are similar within each category, but vary with regard to their effectiveness across the categories.
$>$ Financial relationship marketing programs include discounts, free products, and other monetary benefits that reward customer loyalty. However, if these programs are not enabled by unique sources, any advantage accruing from such marketing is unsustainable as competitors can easily match any special offers. Moreover, such incentives tend to attract deal-prone customers who are less profitable to serve. Nevertheless, in certain situations, financial programs can provide sufficient returns.

> Social relationship marketing programs include meals, special treatment, entertainment and personalized information. The social bonds which result from these are difficult to duplicate and may lead customers to reciprocate via repeat sales and recommendations and to ignore competitive offers. These programs are believed to have a strong impact on relationships.

> Structural relationship marketing programs increase productivity and/or efficiency for customers through investments that they would not make themselves. Examples include customized order processing systems, dedicated personnel, and tailored packaging. These programs typically require considerable setup efforts and offer unique benefits, so that customers may be reluctant to use other suppliers. The bond between buyer and seller is very strong, and may also generate competitive advantages, because the buyer directs more business towards the seller in order to take full advantage of the benefits.

In general, although the three types of program may vary in their scope and effects, all are expected to have a positive impact on customer-specific returns (Refer to figure 1).

Apart from these programs, other factors may influence CSR. Typical B2B customers interact with salespeople and the selling firm; thus customer, salesperson and selling-firm factors could all affect exchange performance. There are two types of customer-related factors: relational (emotional or behavioral) ones, and those related to the customer's specific characteristics. A positive emotional attitude towards the selling firm may induce a commitment caused by the desire to maintain a valued relationship. The key behavioral factors in this context are interaction frequency and relationship duration. Turning to customer characteristics, a customer's sales growth can lead to an increase in the selling firm's sales. Other customer characteristics that may affect 


\section{Figure 1:}

\section{EFFECTS OF RELATIONSHIP MARKETING INVESTMENTS} ON CUSTOMER-SPECIFIC RETURN

\section{LEVERAGING RELATIONSHIP MARKETING INVESTMENTS}

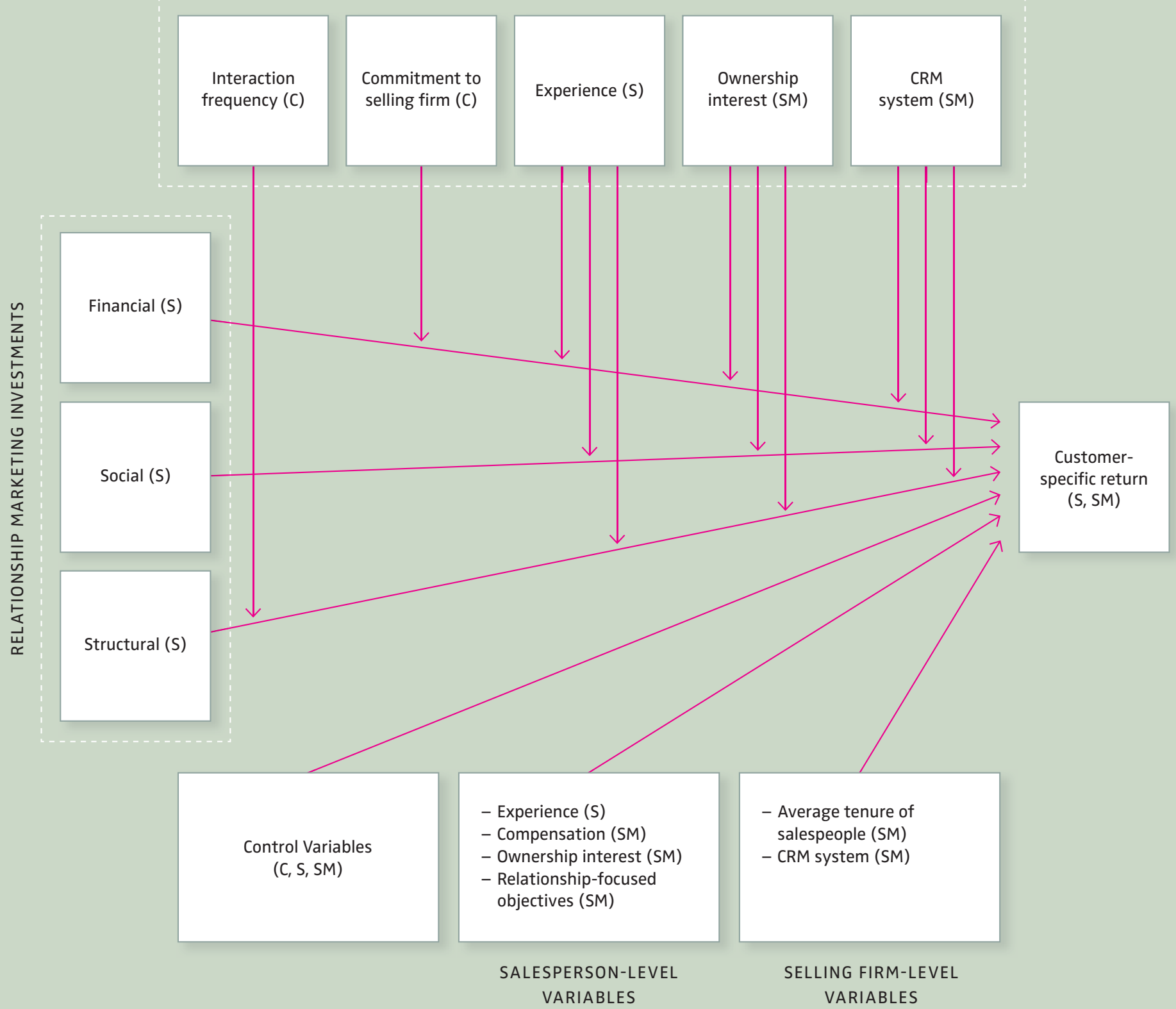


profit are captured within a salesperson's perception of the customer's potential or attractiveness.

As far as the salesperson is concerned, ability and motivation are both important to sales and profit outcomes. Experienced salespeople are better at identifying and closing sales opportunities, and adapt more easily to change. The better their compensation, the more satisfied and motivated they are, which in turn affects the amount of effort they put in to the job. The harder they work, the greater the company's sales and profits should be. If they are given ownership interests, such as profit sharing and stock ownership plans, this is likely to increase their awareness of the way in which their actions affect the company's profit.

Selling-firm factors include direct and indirect efforts to build and maintain profitable customer relationships. One indirect effort is to maximize the average tenure of salespeople at the firm, because it results in stronger customer relationships, fewer customer defections and more customer-specific knowledge. One example of a direct effort is the use of customer relationship management (CRM) - a strategic approach used to create shareholder value by developing relationships with key cus- tomers and customer segments through the use of data and of information technology. In addition, CRM supports relationship marketing by helping firms to target their efforts more effectively, thereby increasing customer-specific profits. Finally, other selling-firm factors include advertising expenditure and the size of the firm.

\section{What factors leverage relationship marketing investments?}

The drivers and variables which may leverage relationship marketing investments across the three exchange participants (customer, salesperson, and selling firm) are summarized in table 1 . We will distinguish between customer-level, salesperson-level and selling-firm-level moderators.

\section{Customer-level moderators}

Two theoretical drivers may leverage the impact of relationship marketing investments: the customer's motivation to have a relationship, and the willingness to reciprocate the seller's investments. A higher return on investment may ensue from customers who desire a relationship and who reward sellers for their relationship-building efforts. Cost savings and tangible benefits from a relationship affect a customer's loyalty. However,
TABLE 1:

Customer, salesperson, and selling-firm variables which leverage the influence of relationship marketing investments on customerspecific return

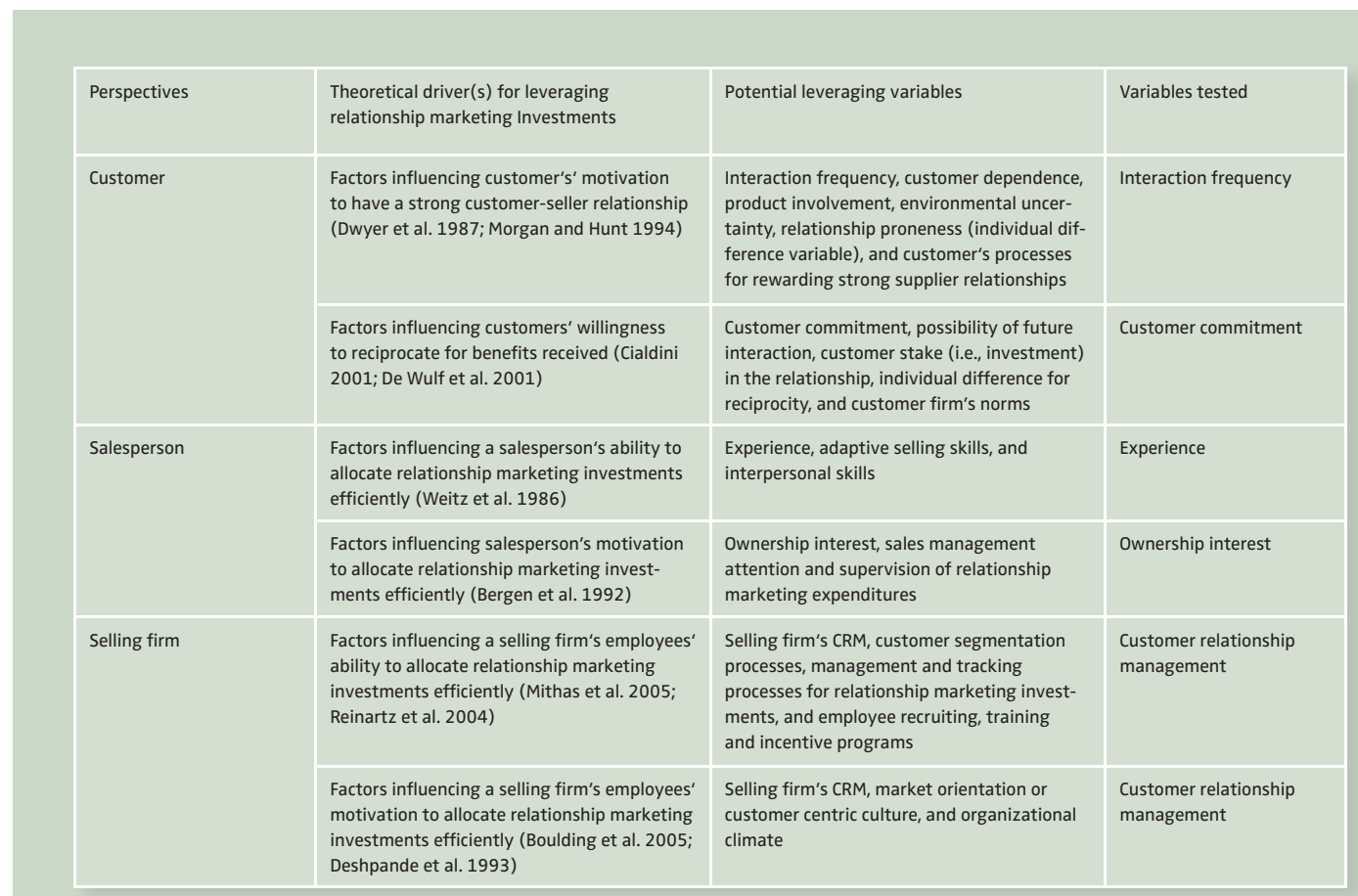


if relationship marketing introduces inefficiencies like added costs or unwanted social interactions, they may cause resentment.

\section{Customer motivation}

Many factors can increase a customer's need or motivation for stronger relational linkages, including customer dependence, interaction frequency, product involvement and environmental uncertainty. Because relationship marketing programs operate through different relational mechanisms, each program must be evaluated separately, in order to determine whether a proposed moderator alters a customer's relational motivation or perceived value. Interaction frequency, for example, has been noted as a way to increase the value of structural relationship marketing for a customer.

As structural programs can increase customer productivity and/or efficiency through a customized interface, more frequent interactions lead to increases in perceived value as customers gain greater productivity during more interactions. The cost to seller and buyer of implementing a structural program is typically fixed, so that after the interface is set up, the additional cost of maintaining the program is minimal. Consequently, customer value increases with interaction frequency, resulting in stronger bonds, enhanced loyalty, and more business to the selling firm.

However, social and financial programs do not have the same effects. In the case of social programs, when a strong relationship has been built, there is little additional value for the customer from more interactions, and the cost to the buyer and seller of maintaining a social bond is more variable. Thus, customers do not perceive higher value from social programs as the frequency of interaction increases. Similarly, this frequency will not affect the value of a financial program as it depends chiefly on economic savings.

\section{Customer's willingness to reciprocate}

The second theoretical driver, the customer's willingness to reciprocate, indicates that relationship marketing will have a greater effect on profit when invested in customers who are willing to reciprocate the value they receive. For example, if a buyer expects to interact with the seller in the future or has a stake in maintaining the exchange, he or she should behave less opportunistically. Efforts towards customers who are committed to maintaining the relationship should generate higher returns because of their likelihood of reciprocating with increased sales or a willingness to pay a price premium. This effect is most likely to occur with programs that require little investment by the customer, in terms of cost, time or effort, to extract value, because such programs offer little protection from opportunism. As social and structural programs require more time and effort to develop than financial ones, a customer's commitment to the selling firm is likely to moderate the profit impact of financial relationship marketing investments.

Salesperson-level and selling-firm-level moderators

At the salesperson and selling-firm levels, a number of variables may influence decision makers' ability and motivation to allocate relationship marketing investments efficiently. For example, experienced salespeople should be effective at choosing and delivering targeted programs to select customers. Relationship marketing should therefore have a greater impact on performance for experienced salespeople.

The ownership effect also plays a critical role in this context, as it motivates salespeople to act in the best interests of the firm. If their earnings are linked to sales revenue and they have no ownership interest, a misalignment may be created. Such salespeople, who have some discretion in allocating their expenditure, may spend aggressively without worrying about the direct costs of the programs. If they do have an ownership interest, they are likely to be more discerning in targeting their relationship-building resources, and thus to minimize inefficient spending.

At the selling-firm level, variables that influence employees' ability or motivation to spend resources wisely on customers should have a greater impact on their performance. In general, CRM motivates and enables employees to allocate marketing resources efficiently by identifying customers who meet criteria for specific programs, evaluating and improving the effectiveness of these programs, and reducing the time needed to implement them. Thus, firms that use CRM should be able to generate higher levels of profits for a given relationship-building investment than others that do not.

\section{Research method and model}

The empirical data used in this study came from industrial customers, salespeople and sales managers of each selling firm. The companies involved were rep firms, which represent several manufacturers as exclusive 
sales agents in specific territories. They do not manufacture or stock the product they sell, and their costs do not vary with small changes in sale volumes, except for the salespeople's variable pay. It is therefore relatively easy to assess the economic impact of relationship marketing in this context.

Rep firms offer two additional advantages when it comes to evaluating the return on relationship marketing investments. First, they sell a range of products from multiple manufacturers, so the influence of any product or brand is minimal. Second, they have few tangible assets, which makes their customer relationship their primary asset.

\section{Sample and data collection}

The final data set included 313 business customers covered by 143 salespeople of 34 rep firms. The sample comprised firms selling in a wide range of end markets, including electronics, electrical, plumbing, telecommunications, and maintenance supplies. On average, 93 percent of their sales were of products rather than services, and 69 percent came from products or services for which customers had alternative suppliers. The average customer bought 3.8 different supplier lines from the rep firm.

How do you measure relationship

investments and returns?

Existing measures were used whenever possible, and all items were tested and refined through interviews with buyers, salespeople, and sales managers. Customers reported their commitment to the selling firm using three items. They also provided single-item measures for the number of interactions per week, the percentage growth rate of the customer firm, and the relationship duration in years.

The salespeople reported their financial, social, and structural relationship marketing investments for each customer. Each salesperson received a list of activities for each program, followed by a question regarding the average monthly spending for this customer over the past year for each activity. This process was repeated for each of the three programs. Finally, salespeople reported the overall sales potential and average commission percentage for each customer, and their experience in years.

Sales managers provided information on the selling firm, the salespeople, and customer sales. For selling firms, they reported the average tenure of salespeople in years, whether they used CRM, advertising spend, and the size of the selling firm in millions of dollars. For each salesperson, sales managers reported compensation in dollars, whether they had an ownership interest, and whether a relationship-focused objective applied. They also provided two years of archival sales data for each customer, which was used to calculate the returns. The CSR for each customer was calculated by multiplying the sales revenue by the effective commission rate for that customer. Thus, CSR represents the contribution margin a rep firm earns on sales, which remains valid until incremental sales require additional selling costs.

The effects of relationship marketing expenditure are likely to play out over time as customer relationships evolve. In order to capture the effect of prior expenditure, the CSR for the previous period is also included, thereby giving a lagged effect. Secondly, variables are included in addition to relationship marketing expenditures at the three different levels, and the relevant interaction effects are noted.

\section{The real productivity of relationship marketing: empirical results}

The model demonstrated in figure 2 offers an insight into the complex effects of relationship marketing on CSR. One advantage of this model is that the parameter estimates for relationship marketing investments can be interpreted as the marginal return for each type of program. In this sample, for instance, a $\$ 1,000$ additional investment in social relationship marketing generates $\$ 1,775$ of incremental profit, a 78 percent return, for when other variables in the model are controlled. Because financial and structural programs have significant interactions, the level of the moderators must be accounted for when the results are interpreted.

Investments in structural programs have a positive direct effect on CSR, but generate higher returns for those customers with a high interaction frequency. For example, at two interactions per week, the programs appear to break even, but when customers engage in four interactions per week, a \$1,000 investment in structural relationship marketing generates $\$ 1,231$ of profit, a 23 percent return.

Financial relationship marketing has no significant direct correlation with CSR, although variables at each hierarchical level demonstrate significant interactions with financial relationship marketing, namely commitment to the selling firm, ownership interest and the absence of a 
Figure 2:

\section{RESULTS: DIRECT AND INDIRECT EFFECTS OF RELATIONSHIP MARKETING INVESTMENTS ON CUSTOMER SPECIFIC RETURNS}

EFFECTS OF RM INVESTMENTS

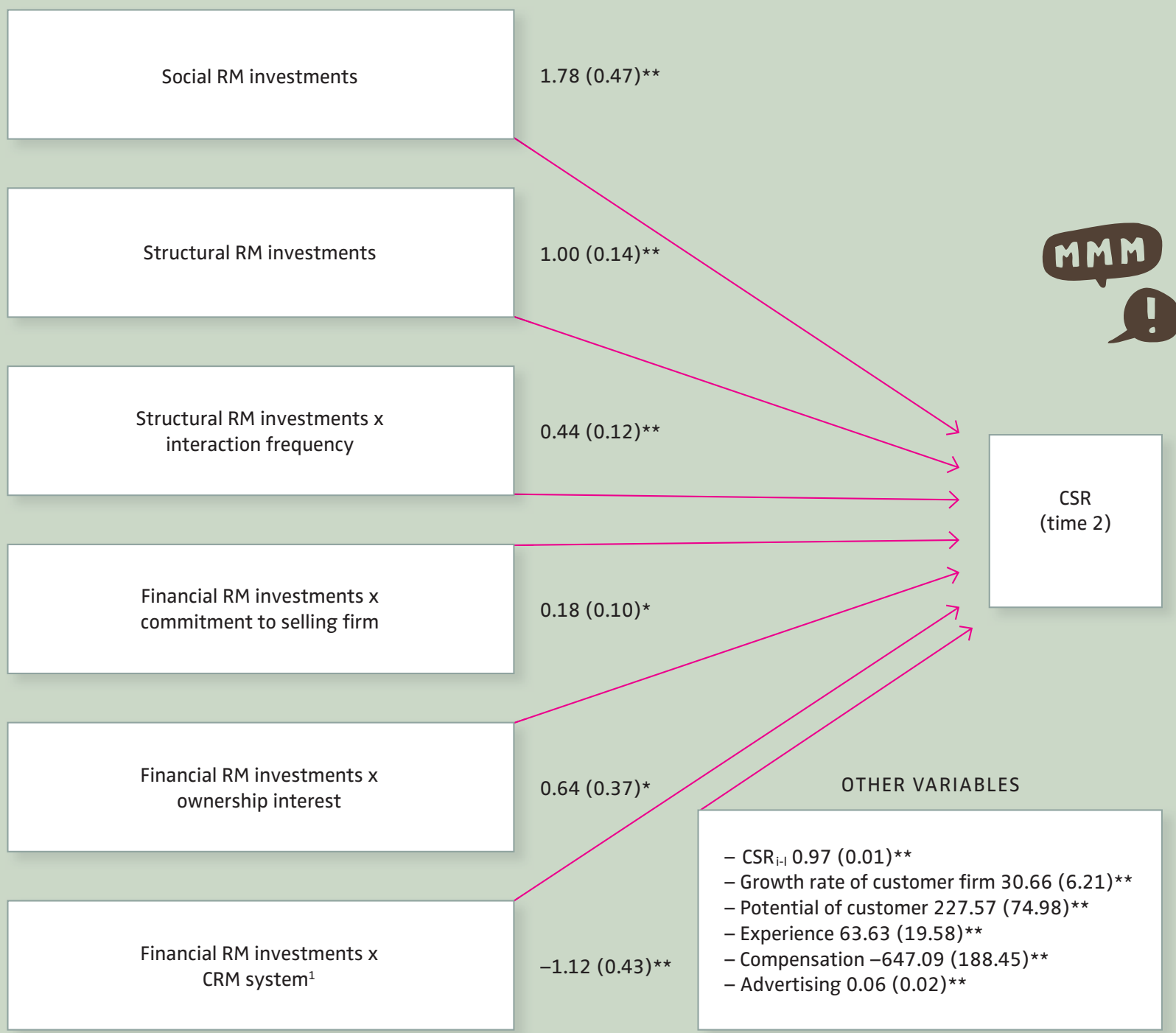

Notes:

Unstandardized parameter estimates (standard error) are shown for each significant effect.

Relationship Marketing (RM), Customer Relationship Management (CRM), customer-specific return (CSR)

1) Negative coefficient represents the effect of not having a CRM system.

* $\mathrm{p}<0.05$

$* * p<0.01$ 


\section{») Social expenditure impacts on profit, and thereby reaffirms the notion that such investments are worthwile and can translate to goodwill among B2B customers. «}

CRM system. For example, even with committed customers, salespeople who have an ownership interest and a selling firm that employs CRM, investing $\$ 1,000$ in financial relationship marketing produces only a $\$ 686$ return - in other words, a 31 percent loss.

In addition to the relationship marketing variables, other moderators are included at the three levels. At the customer level, previous-period CSR, customer growth rate and customer potential have significant positive effects on profit. At the salesperson level, experience has a strong positive effect, but salesperson compensation has a significant negative impact on CSR, contrary to the expectations referred to in the second section of the study. Post-hoc discussions with sales managers indicate that the negative impact of total compensation on CSR may be due to highly compensated salespeople reaching a plateau and ceasing to sell aggressively. At the firm level, advertising dollars have a positive impact on profit.

To summarize, the study models the customer-specific payoff for financial, social, and structural relationship marketing investments, provides a theoretical framework of customer, salesperson, and selling-firm factors which may enhance relationship marketing productivity, and provides empirical support for this framework by identifying four variables that leverage the impact of relationship marketing on CSR.

The results of the survey are closely aligned with two recent trends in marketing: determining the return on marketing expenditure, and moving towards one-to-one customer marketing. They also support the assumption that relationship marketing programs differ in their effectiveness, so if the same financial resources are invested in financial, social and structural relationship programs respectively, they often give very different rates of return. In this empirical study, the return on additional investment in social relationship programs is 78 percent, whereas that on structural relationship marketing is just 23 percent.

Secondly, the influence of relationship marketing on CSR is leveraged by factors associated with each of the three exchange participants: the customer, salesperson, and selling firm. This finding indicates that program returns are not arbitrary, and may be improved using a variety of strategies, including customer segmentation, salesperson selection, training, incentives, and selling firm initiatives. Thirdly, any company deciding to invest in relationship marketing must bear in mind that certain moderators can affect the profitability of the program, and even result in a loss.

The findings of the study suggest that social expenditure has a direct and significant impact on profit, and thereby reaffirm the notion that such investments are worthwhile and can translate to goodwill among B2B customers. Social investments appear to deliver the highest short-term return, which may be due to the immediacy of social relationship marketing, in that sellers can implement social programs in response to current events with little prior planning. Social programs may also create a feeling of personal indebtedness, making customers want to reciprocate and thus generating immediate returns.

Structural relationship marketing investments generate positive short-term economic returns from those customers with above-average interaction frequencies of more than twice a week, which makes these programs attractive for some customers. Sellers can leverage their structural relationship marketing resources by targeting customers with relatively frequent interactions, for whom customized structural solutions offer the most value. Structural linkages should also have an ongoing impact on future profits; although short-term customer response may be based on reciprocation for a perceived investment, customers should continue to take advantage of the value provided by these structural interfaces in the long run. 
The return on financial relationship marketing expenditure varies a great deal depending on customer, salesperson, and selling firm factors, although the main effect is not significant and fails to generate positive returns in any context evaluated in this study. The lack of positive short-term returns is probably linked to the ease with which competitors can match incentives and financial marketing resources can be misallocated.

However, although financial relationship marketing is not economically viable in the short term, it may have an important strategic role. Firstly, such investments may be necessary to respond to competitive threats and protect existing business, rather than as a means of generating new business. This reasoning implies that financial relationship marketing may be more defensive, whereas social and structural relationship marketing is a more offensive relational weapon. Secondly, an important component of customer portfolio management involves attracting less valuable customers and building relationships that may grow in the long run, though this strategy is open to misallocation of resources.

For example, it is relatively easy for a customer service employee or salesperson to provide a financial incentive such as a free sample or special discount, whereas building a personal relationship or implementing a structural program requires much greater investments of time and effort. Thirdly, the findings are consistent with the premise that the advantage of CRM may not be to influence profits directly, but rather to improve the targeting of marketing efforts.

Another important aspect of this research is its investigation of the effects of relationship marketing on customers, salespeople and selling firms. Here, it finds that 61.9 percent of the variance in CSR comes from the customer level, which reinforces the importance of customer-level variables. Only 9.5 percent of variance is at the salesperson level, which is surprising given the perception of salespeople as playing a critical role in the process. The remaining 28.5 percent of CSR variance comes at the firm level, so firm-level strategies are clearly vital to performance.

\section{Implications}

Several implications can be drawn from these results. Firstly, managers should have greater confidence in relationship marketing programs, because they work and because they have a measurable impact on bottom-

\begin{tabular}{|c|c|c|c|}
\hline Description of scenario & $\begin{array}{c}\text { Financial relationship } \\
\text { marketing } \\
\text { investments (\%) }\end{array}$ & $\begin{array}{c}\text { Social relationship } \\
\text { marketing } \\
\text { investments (\%) }\end{array}$ & $\begin{array}{c}\text { Structural relationship } \\
\text { marketing } \\
\text { investments (\%) }\end{array}$ \\
\hline Overall sample & 0 & 69 & 31 \\
\hline Ownership interest & 8 & 71 & 21 \\
\hline No ownership interest & 0 & 64 & 26 \\
\hline No CRM sytem & 0 & 74 & 27 \\
\hline
\end{tabular}

TABLE 2:

Optimal relationship marketing allocation 
line results. In addition, the ability to document these economic returns provides managers with a strong argument when requesting resources to spend on relationship marketing.

Second, the study identifies the circumstances in which relationship marketing programs can best be employed. For example, firms may be underspending on social programs, and additional investments could generate greater profits. As structural programs offer the greatest returns when directed towards those customers with whom the firm interacts frequently, managers could target their structural investments toward these customers.

However, the recommendations for financial programs are more complex. The returns from these programs are improved when the selling firm has CRM in place, the salesperson has an ownership interest, and customers are committed to the selling firm. Nevertheless, as a standalone investment, they are not viable in the short term and should only be used strategically to respond to competitors or to attract new customers, rather than with the expectation of a short-term increase in profit. Overall, managers should develop a profile of customers or customer segments that can become the focus of targeted relationship marketing efforts, and vary the mix of programs according to the characteristics of each segment.

Because financial, social, and structural relationship marketing resources provide different returns, allocating them across programs is a complex challenge that must take account of customer interaction, salesperson and selling-firm factors. So how should a manager allocate a given budget across relationship marketing programs? To answer this question, the study develops a post-hoc resource allocation model that provides insights into the optimal mix of relationship marketing programs for a given budget and for different salesperson and selling firm strategies (Refer to table 2).

The optimization model indicates that in this sample, sellers should allocate about two thirds of their spending to social programs, one third to structural programs, and nothing to financial programs. It makes sense to allocate 8 percent to financial relationship marketing if the salespeople involved have an ownership interest, but otherwise such investments do not pay off. Similarly, when the selling firm has a CRM system in place, around 7 percent of relationship marketing resources may be shifted to financial programs.
In the five scenarios in table 2, social investment ranges from 64 to 74 percent of the total spend, which implies that it should be the key focus of any relationship marketing portfolio. Structural investment varies between 21 and 36 percent, with the recommended allocations being highest for structural programs and lowest for social programs in the "no ownership" group, suggesting that when salespeople have little stake in the company's profitability, they may be less effective at building strong relationships with customers, more likely to defect to competitors, and more prone to allocating their social investment poorly.

\section{Conclusion}

This research investigates the impact of a selling firm's relationship marketing expenditure on the profit it makes from each customer. It identifies twenty-five potential variables which can leverage this spending. A significant level of moderation was found across all three exchange constituents (customer, salesperson, and selling firm) and all three theoretical drivers (motivation to build a relationship, customer's willingness to reciprocate, and seller's ability to allocate resources efficiently).

Social programs have the highest payoff, probably because salespeople quickly adapt by channeling their investment into those which offer the highest returns. Of course, the results of the study are not valid for all firms and all situations. The analysis focuses on a context in which relationship marketing is critical to the sustainability of the business, and it would therefore be useful to replicate the approach in contexts in which relationship marketing does not have such a central role as with the rep firms in this research. Also, the study does not consider the effects over periods of more than one year, or economy- and industry-specific issues. A study examining the impact of relationship marketing expenditure, alternative relationship marketing typologies, and different measurement methods would therefore be valuable.

Furthermore, although short-term economic returns from investment decisions are critical to managers, relationship marketing programs should generate other long-term outcomes not included in the study data, such as cross-selling and upselling. Further research could attempt to explore the long-term payoff of relationship marketing investments by including such variables. • 


\section{APPENDIX A. CONSTRUCT MEASURES}

\begin{tabular}{|c|c|}
\hline Measures (units) & Source \\
\hline $\begin{array}{l}\text { Interaction frequency (interactions per week) } \\
\text { How many times do you interact with this rep firm in a typical week? }\end{array}$ & Customer \\
\hline $\begin{array}{l}\text { Commitment to the selling firm (average of three 7-point Likert scale items, } \alpha=0.95 \text { ) } \\
\text { I am willing "to go the extra mile" to work with this rep firm. } \\
\text { I feel committed to my relationship with this rep firm. } \\
\text { I view the relationship with this rep firm as a long-term partnership. }\end{array}$ & Customer \\
\hline $\begin{array}{l}\text { Growth rate of customer firm (\%) } \\
\text { What is your estimate of your company's growth over the past year? }\end{array}$ & Customer \\
\hline $\begin{array}{l}\text { Relationship duration (years) } \\
\text { How long have you had business dealings with this rep firm in your career? }\end{array}$ & Customer \\
\hline $\begin{array}{l}\text { Financial relationship marketing investments (annualized \$) } \\
\text { This customer often gets free product and services. } \\
\text { This customer frequently gets special pricing or discounts. } \\
\text { This customer receives special financial benefits and incentives. } \\
\text { The average monthly cost to provide the financial benefits listed above is... }\end{array}$ & Salesperson \\
\hline $\begin{array}{l}\text { Social relationship marketing investments (annualized \$) } \\
\text { This customer is often provided meals, entertainment or gifts by me or my rep firm. } \\
\text { This customer often receives special treatment or status. } \\
\text { This customer often receives special reports or information. } \\
\text { The average monthly cost to provide the social benefits listed above is... }\end{array}$ & Salesperson \\
\hline $\begin{array}{l}\text { Structural relationship marketing investments (annualized \$) } \\
\text { This customer often receives special value-added benefits (inventory control, expediting, etc.). } \\
\text { Special structural changes (EDI, packaging, etc.) have been instituted for this customer. } \\
\text { Our policies and procedures are often adapted for this customer. } \\
\text { Dedicated personnel are assigned to this customer beyond what is typical for our rep firm. } \\
\text { The average monthly cost to provide the structural benefits listed above is... }\end{array}$ & Salesperson \\
\hline $\begin{array}{l}\text { Potential of customer (seven-point Likert scale) } \\
\text { The customer represents a large potential opportunity for me. }\end{array}$ & Salesperson \\
\hline $\begin{array}{l}\text { Experience (years) } \\
\text { How many years have you worked for any rep firm including this one? }\end{array}$ & Salesperson \\
\hline $\begin{array}{l}\text { CSR }(\$) \\
C S R=(\text { Sales to customer }) *(\text { average commission at customer }) *(1-\text { salesperson variable pay }) \text {, sales to customer }(\$) \text { and salesperson variable pay }(\%) \\
\text { reported by sales manager; average commission reported by salesperson for each customer }(\%) .\end{array}$ & $\begin{array}{l}\text { Sales manager } \\
\text { and salesperson }\end{array}$ \\
\hline The next three questions regarding salesperson compensation were prefaced by: "Please answer the following questions for each salesperson listed." & \\
\hline $\begin{array}{l}\text { Compensation ( } 1:<30 \mathrm{k} \$, 2: 30 \mathrm{k} \$ \text { to } 60 \mathrm{k} \$, 3: 60 \mathrm{k} \$ \text { to } 90 \mathrm{k} \$, 4: 90 \mathrm{k} \$ \text { to } 120 \mathrm{k} 0,5:>120 \mathrm{k} \$) \\
\text { Total } 2002 \text { compensation }\end{array}$ & Sales manager \\
\hline $\begin{array}{l}\text { Ownership interest ( } 0: 0 \% \text { ownership interest in selling firm, 1: }>0 \% \text { ownership interest in selling firm) } \\
\% \text { of salesperson's ownership in the rep firm }\end{array}$ & Sales manager \\
\hline $\begin{array}{l}\text { Relationship-focused objectives ( } 0: 0 \% \text { of compensation based on relationship-focused objectives, } 1:>0 \% \text { of compensation based on relationship-focused objectives) } \\
>0 \% \text { of compensation based on relationship-facused objectives } \\
\% \text { of total compensation which was based on customer satisfaction or relationship objectives }\end{array}$ & Sales manager \\
\hline $\begin{array}{l}\text { Advertising (annual spending in dollars) } \\
\text { How much did your rep firm spend in } 2002 \text { on all types of marketing programs including tradeshows, advertising, brochures, etc.? }\end{array}$ & Sales manager \\
\hline $\begin{array}{l}\text { Selling firm size (annual sales in million of dollars) } \\
\text { What was your rep firm's approximate annual sales for 2002? }\end{array}$ & Sales manager \\
\hline $\begin{array}{l}\text { Average tenure of salespeople (years) } \\
\text { How many years does an outside salesperson typically stay at your rep firm? }\end{array}$ & Sales manager \\
\hline $\begin{array}{l}\text { CRM system (0: employ CRM system, } 1 \text { : no CRM system) } \\
\text { Did your rep firm utilize a CRM in 2002? }\end{array}$ & Sales manager \\
\hline
\end{tabular}

